\title{
XXXVII. On the generation of electric currents by sulphur cells
}

\section{Shelford Bidwell M.A. LL.B.}

To cite this article: Shelford Bidwell M.A. LL.B. (1885) XXXVII. On the generation of electric currents by sulphur cells, Philosophical Magazine Series 5, 20:125, 328-336, DOI: $10.1080 / 14786448508627765$

To link to this article: http://dx.doi.org/10.1080/14786448508627765

曲 Published online: 29 Apr 2009.

Submit your article to this journal $₫$

Џll Article views: 2

Q View related articles $₫$ 
TABLE III.

\begin{tabular}{|c|c||c|c||c|c|}
\hline $\begin{array}{c}\text { Rate of } \\
\text { oxidation, } \\
\rho .\end{array}$ & $\begin{array}{c}\text { Value for } \\
n .\end{array}$ & $\begin{array}{c}\text { Rate of } \\
\text { oxidation, } \\
\rho .\end{array}$ & $\begin{array}{c}\text { Value for } \\
n .\end{array}$ & $\begin{array}{c}\text { Rate of } \\
\text { oxidation, } \\
\rho .\end{array}$ & $\begin{array}{c}\text { Value for } \\
n .\end{array}$ \\
\hline $1 \cdot 10$ & $10 \cdot 5$ & $1 \cdot 92$ & $8 \cdot 1$ & $3 \cdot 32$ & $5 \cdot 8$ \\
$1 \cdot 21$ & 10 & $2 \cdot 11$ & $7 \cdot 7$ & $3 \cdot 59$ & $5 \cdot 6$ \\
$1 \cdot 33$ & $9 \cdot 6$ & $2 \cdot 29$ & $7 \cdot 5$ & $3 \cdot 83$ & $5 \cdot 6$ \\
$1 \cdot 46$ & $9 \cdot 2$ & $2 \cdot 51$ & $7 \cdot 1$ & $5 \cdot 08$ & $4 \cdot 3$ \\
$1 \cdot 62$ & $8 \cdot 3$ & $2 \cdot 73$ & $6 \cdot 8$ & $6 \cdot 04$ & $3 \cdot 7$ \\
$1 \cdot 73$ & 9 & $2 \cdot 96$ & $6 \cdot 6$ & $7 \cdot 15$ & $3 \cdot 1$ \\
\hline
\end{tabular}

From this Table it will be seen that $n$, instead of having a constant value, gradually diminishes as the temperature increases, but that for a few consecutive experiments the differences are such as might be referred to experimental errors, and so lead to the erroneous supposition that $\rho \propto \theta^{2}$.

So far as these experiments go, it would seem probable that, for this reaction at least, the temperature function is of an exponential form. Indeed, in many cases of chemical change it is a common observation that the speed increases very rapidly with the temperature, being, as Lemoine remarks, characteristic of an exponential form. In the course of some experiments on retardation, in which ferrous chloride was the material employed, instead of sulphate as in the present case, it has been found that here also, in presence of agents that retard the oxidation very considerably, the relation between rate and temperature may be represented in the form $\rho=a a^{\theta}$. A full account of these experiments, however, will, it is hoped, be given at a future time.

XXXVII. On the Generation of Electric Currents by Sulphur Cells. By Shelford Bidwell, M.A., LL.B.*

TN a communication recently made to the Physical Society $\dagger$ I I ventured the suggestion that the electric conduction of selenium, when prepared in such a form as to be sensitive to light, was, in the literal sense of the term, electrolytic. Selenium itself indeed could bardly be supposed to be an electrolyte; but it was pointed out that when selenium was "annealed" in contact with metallic electrodes, metallic selenides would, at least in most cases, be formed in sufficient quantity to account for the electrolytic phenomena observed; and that even if this were not the case when the electrodes consisted of such a metal as platinum, yet the necessary metallic element

* Communicated by the Physical Society : read June 27, 1885.

† Phil. Mag. August 1885. 
might possibly be found in the lead, iron, and arsenic which are contained as impurities in ordinary commercial selenium. Little direct evidence was offered in support of this view; but it was shown that sulphur, when mixed with a certain proportion of sulphide of silver and arranged in the form of a "cell" with silver electrodes, exhibited many of the properties of crystalline selenium, especially that of having its electrical resistance temporarily diminished under the influence of light. Analogy therefore tended to confirm the opinion which I had been led to entertain.

While observing the secondary or polarization-currents which are generated by sulphur cells (as by those made with selenium), after being disconnected from a battery, certain effects were noticed which seemed to indicate that when the electrodes consisted of two different metals, a sulphur cell might be capable of originating and maintaining an independent or primary current. Experiments were therefore made with the object of investigating this point; and the present paper contains an account of the results obtained. I have bardly attempted to connect them together by any complete theory: of some of them, indeed, I can offer no explanation whatever; others appear to be in direct opposition to what might have been expected. But, so far as I have been able to ascertain, they are entirely novel, and of sufficient interest to be worthy of record.

(1) A slip of mica was wound with two parallel wires of silver and copper 1 millim. apart, and melted sulphur containing a small quantity of precipitated sulphides of silver and copper was spread over one surface. It is not known what proportion of the sulphides was contained in the mixture, because the bulk of them sank to the bottom of the crucible in which the sulphur was melted. When cold, the cell was connected with a reflecting galvanometer, and was found to generate a small but steady current, indicated by a deflection of about 20 scale-divisions. When the connections of the cell were reversed, the current was reversed. It was therefore not due to any thermo-effect in the circuit. The direction of the current was from silver to copper through sulphur: its strength was diminished by exposure to light, and increased by rise of temperature. Connecting the free ends of the silver and copper wires and heating the junction, it was found that the thermo-current thus produced passed (as usual) from copper to silver through the junction. The increase of current by heat was therefore not to be accounted for by thermoelectric action, for that would produce the opposite effect. 
The action is almost certainly of the same nature as that which occurs in an ordinary voltaic cell.

(2) It appeared desirable to construct a cell which, though unsuitable for experiments with light, would have a much smaller resistance than one of the form last described. A plate of copper 3 centim. square was heated, and upon it was spread a mixture consisting of 5 parts of sulphur and 1 part of sulphide of copper. A plate of silver previously heated was then laid on the melted mixture and the two plates squeezed together, thus forming a sandwich-like cell. The thickness of the copper plate was $2 \cdot 75$ millim., of the silver plate 60 millim., and of the completed cell 3.65 millim.; the thickness of the layer of sulphur was therefore $\cdot 3$ millim. When this cell (after cooling) was connected with the galvanometer, the spot of light was violently deflected off the scale. Dr. Fleming was kind enough to make a very accurate measurement of its electromotive force by comparison with one of his standard Daniell cells. It was found to be $\cdot 0712$ volt, and its internal resistance was $6537 \mathrm{ohms}$. As in the case of the former cell, the direction of the current is from silver to copper; and there can be no doubt that it is of a voltaic nature. At the time of writing, the cell has been in existence nearly seven weeks, and it is now, I believe, quite as powerful as at first.

(3) It was thought that the internal resistance might be further reduced by adding a larger proportion of sulphide to the sulphur. Another cell was therefore constructed similar in all respects to that last described, except that the sulphur and copper sulphide were mixed in equal proportions. Its internal resistance was enormously lower, being only $13 \mathrm{ohms,}$ but its E.M.F. was also lower, being 0071 volt.

(4) A layer of precipitated sulphide of copper was placed between plates of copper and silver which were squeezed together in a screw-press. The resistance of this arrangement was a small fraction of an ohm; but when connected with the galvanometer, it gave no indication whatever of a current. It seems, therefore, that a certain amount of free sulphur is necessary for the generation of an electromotive force by cells containing copper sulphide.

(5) Two parts of copper sulphide were mixed with one of sublimed sulphur, and the powder was compressed between plates of copper and silver. This cell gave a very small current, indicated by a galvanometer-deflection of 2 or 3 scaledivisions. The deflection was reversed as often as the connections with the binding-screws of the cell were reversed; and the existence of a real, though very small, electromotive force was undoubted. The internal resistance was $088 \mathrm{ohm}$. 
(6) The last-mentioned cell was taken to pieces and remade after the addition of about an equal part of sublimed sulphur to the mixture of sulphur and sulphide. Its resistance was now found to be many megohms, yet it produced a larger galvanometer-deflection than before.

(7) Once more the cell was taken to pieces and a little more sulphide added. When remade, its resistance was at first about $2700 \mathrm{ohms}$; but it varied considerably. It produced a galvanometer-deflection of about 100 divisions, which in a few minutes increased in a somewhat irregular manner to 250 divisions. It was then disconnected from the galvanometer, and, when again connected after an interval of six hours, it deflected the spot of light off the scale. Shunting the galvanometer (the resistance of which was $3483 \mathrm{ohms}$ ) with a coil of $300 \mathrm{ohms}$, the deflection amounted to 130 divisions; and on the following day with the same shunt, the deflection was at first about 250 divisions, rapidly diminishing, however, when the circuit was closed.

(8) A cell was made by compressing precipitated silver sulphide unmixed with any free sulphur between plates of silver and copper. When connected with the galvanometer, this cell produced a deflection which, with a shunt of $35 \mathrm{ohms}$, exceeded 400 divisions. But in this case the silver was the negative plate, the direction of the current being from copper through sulphide to silver. The E.M.F. was less than that of the cell described in (2).

(9) Another cell was made in the same manner as that described in (2); but the sulphur was mixed with sulphide of silver instead of sulphide of copper. This gave a strong current in the same direction as that produced when sulphide of copper was used, and opposite to that generated by the cell containing silver sulphide without free sulphur.

(10) Pure sulphur was melted on a clean plate of copper, and, when just liquid, a warmed plate of silver was laid upon it and pressed down with a weight until cold. This cell gave a strong current from silver through sulphur to copper. Sulphides were of course formed during the process of construction.

(11) A melted mixture of sulphur and silver sulphide was spread upon a copper plate, and a plate of silver pressed upon it. When cold, the silver plate was split off with a knife, and a piece of silver-leaf, sufficiently thin to appear blue by transmitted light, was attached (by rubbing) to the exposed surface of the mixture. As before, there was a comparatively strong current from the silver to the copper. The silvered surface was then exposed to the light of burning magnesium wire, and 
the immediate movement of the spot of light through 50 scaledivisions indicated a diminution of the current. When the magnesium was extinguished, the current at once increased to its original strength. When a nearly red-hot brass rod was held at a distance of 3 centims. from the silvered surface, the current slowly increased in strength; and when the hot rod was removed, the current was again slowly diminished. The effects both of light and of heat were verified by many repetitions of the experiments. These results which, so far as regards the effect of light, were unexpected, are of the same character as those described in (1). I have elsewhere* given strong reasons for believing that the combination of sulphur with silver is assisted by the influence of light. If this is so, it is certainly a remarkable fact that increased corrosion of the silver electrode should be accompanied by diminution of the current.

Two days afterwards the silver-leaf had become much discoloured, and was in some parts quite black. When connected with the galvanometer the cell gave a current of nearly the same strength as before; but now it was found to be slightly increased by light as well as by heat; and it is probable that the light as such exerted no influence whatever, the observed effect being really due to the incidental rise of temperature.

(12) The silver-leaf was scraped off, and the surface of the sulphur mixture having been cleaned from all visible traces of free silver with fine emery-cloth, a piece of thin goldleaf was pressed upon it. It was found very difficult to make it adhere satisfactorily. The cell, when connected with the galvanometer, gave no indication whatever of a current. When the cell described in (2) was also inserted in the circuit, the spot of light was deflected, showing that the first cell was quite able to conduct electricity, and that its failure to originate a current was not owing to bad contact between the goldleaf and the sulphur mixture.

(13) A cell containing a mixture of sulphur and silver sulphide between plates of silver and iron was found to have an E.M.F. of $\cdot 023$ volt, or about one third of that of the silvercopper cell described in (2). The direction of the current was the same.

(14) A cell was made by melting sublimed sulphur upon a plate of copper and pressing a plate of iron upon the melted sulphur. On connecting it (when cold) with the galvanometer, there was no indication of any current. Nevertheless the cell was found to conduct electricity very well when a

* Phil. Mag. August 1885. 
battery was also placed in the circuit. Sulphide of copper was of course formed by the action of the hot sulphur upon the copper.

(15) A melted mixture of 5 parts of sulphur with 1 part of copper sulphide was pressed between plates of silver and iron, and cooled. When first made, this cell generated a sufficiently strong current to deflect the galvanometer-needle as far as the stop would allow; but two hours later, when an attempt was made to measure the E.M.F., it was found to have almost completely disappeared, being less than a hundredth of that of the cell described in (2). The E.M.F. was temporarily restored by connecting the iron and silver plates with the positive and negative terminals of a battery of ten Leclanché cells for a few minutes. The result was of course merely a polarization-current.

(16) Two silver wires A, B were imbedded in a fused mass consisting of equal parts of sulphur and copper sulphide. When cold, the wire $A$ was connected with the carbon pole of a battery of ten Leclanché cells, and the wire $B$ with the zine pole. After the current had passed for about a second, the cell was detached from the battery and connected with the galvanometer. A current was at once indicated in the direction $\mathrm{A} \mathrm{B}, i . e$. in the same direction as that of the batterycurrent which had been caused to pass through the cell. This experiment was repeated many times and on different days, with the same result*. A period of some seconds necessarily elapsed between the separation of the cell from the battery and its attachment to the galvanometer. In order to render this interval as short as possible, the apparatus was so arranged that by depressing a key the transfer could be effected in a small fraction of a second. It was then found that the first effect of the transfer was a strong momentary current in the direction $\mathrm{BA}$, which was immediately followed by the more permanent current previously observed in the direction A B. With the view of retarding the first effect, a battery of two Leclanché cells was used, and the connection was made for a longer period. After the battery had been connected for one minute, the cell was transferred to the galvanometer by means of the key, and the swing of the spot of light through 280 scale-divisions again indicated a current in the direction B A. Though this was not, as before, a current of only momentaryduration, it rapidly decreased in strength, becoming zero in almost exactly 30 seconds. After zero was passed, a current was at once set up in the opposite direction $\mathrm{A} B$, which

* The experiments described in the remainder of this paragraph were made after the paper was read. 
in 30 seconds produced a deflection of 70 divisions, increasing to a maximum of 131 divisions in 10 minutes. The current then slowly diminished; and in $5 \frac{3}{4}$ hours after the commencement of the experiment the deflection had fallen to 17 scaledivisions. At this point the observations were discontinued. In the accompanying curve the abscissa represent the time in hours, and the ordinates the current in scale-divisions. The current of 30 seconds' duration in the direction $\mathrm{BA}$ is not represented.

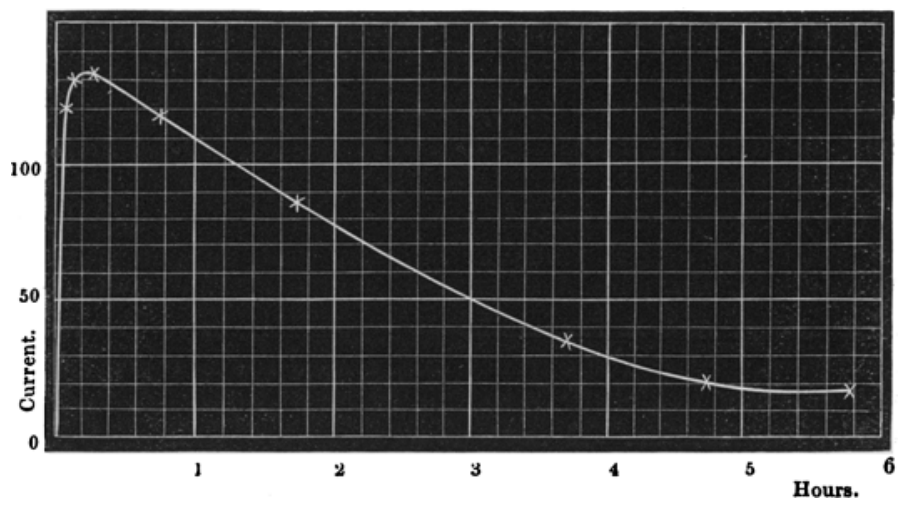

On another occasion, when the two Leclanché cells had been connected for 3 minutes, the secondary current from $B$ to $A$ decreased still more slowly than in the last-mentioned experiment, vanishing in $3 \frac{1}{2}$ minutes. The current which followed in the direction $\mathrm{A} \mathrm{B}$ attained its maximum, indicated by 155 divisions, in $6 \frac{1}{2}$ minutes, and then steadily decreased for nearly 4 hours, when it again became zero. The spot of light did not, however, remain stationary, but moved steadily on, indicating a second reversal of the current. In one hour after zero had thus been crossed for the second time, the galvanometer-deflection was 12 scale-divisions; and $4 \frac{1}{2}$ hours later, when the last observation was made, it had increased to 20 divisions. In both these experiments the galvanometer (of which the resistance was nearly $3500 \mathrm{ohms}$ ) was shunted with a coil of 100 ohms.

These alternating currents are probably of the same nature as those which Faraday found to be generated when copper and silver, or two pieces of copper, or two pieces of silver, were immersod in a solution of potassium sulphide*. The wires are alternately protected from the action of the free sulphur by an investing coat of sulphide.

* Exp. Res. \$§ 1911 and 2036. 


\section{Summary.}

Plates of silver and copper imbedded in a mixture of sulphur with sulphides of copper or silver constitute a cell which at the ordinary temperature is capable of generating and maintaining a constant current, the silver being the positive element. Such a cell, in which the mixture consisted of 5 parts of sulphur with one of copper sulphide between plates 3 centim. square and $\cdot 3$ millim. apart, had an E.M.F. of $\cdot 0712$ volt and an internal resistance of $6537 \mathrm{ohms}$.

If the proportion of copper sulphide to sulphur is increased, the internal resistance of the cell is diminished ; but its.E.M.F. is also diminished.

A cell containing copper sulphide unmixed with free sulphur fails to produce any appreciable current.

A cell containing silver sulphide only generates a current in the opposite direction to that produced when the sulphide is mixed with free sulphur.

Copper used in conjunction with iron or gold gives no current whatever at the ordinary temperature.

The current generated by a silver-copper cell containing free sulphur mixed with sulphide is diminished by the action of light and increased by heat. It has not been ascertained whether the effect is upon the E.M.F. or the internal resistance, or both.

If a battery-current is caused to pass for a short time through a cell consisting of two silver electrodes imbedded in a mixture of sulphur and copper sulphide, the cell, after being disconnected from the battery, will generate a current of very short duration in the direction opposite to that of the battery-current, followed by a current which may be maintained for several hours in the same direction as the battery-current. A second reversal has in one case been found to occur after an interval of four hours.

The experiments, of which an account is here given, must be considered as being merely of a preliminary nature. A complete investigation of the phenomena in question would require more time than $I$ am at present able to devote to the subject.

\section{Addition, August 3rd.}

From (4), (5), and (6) it appears that a cell consisting of copper and silver plates is incapable of generating a current unless a certain proportion of free sulphur is mixed with the sulphide. Thinking that the function of the free sulphur 
might be merely to form silver sulphide by direct combination with the silver, I constructed a cell as follows :-A laver of copper sulphide was spread upon a plate of copper ; a polished steel plate was laid upon the sulphide, and the whole was strongly compressed in a vice. The steel plate was then removed, and a thin layer of silver sulphide was spread upon the smonth surface of the copper sulphide. The cell was completed by pressing a silver plate upon the silver sulphide. This was found upon trial to give a current which, with an external circuit of low resistance, was many times stronger than that generated by any of the cells previously made. It seems to be exactly analogous in its action to a Daniell cell consisting of plates of zine and copper in solutions of zine sulphate and copper sulphate. The quantity of the copper sulphide would be gradually diminished, copper being deposited on the copper plate, while the quantity of silver sulphide would continually increase with consumption of the silver.

In conclusion, it seems probable that, by selecting such metals as experiment might prove to be better suited for the purpose than silver and copper, a cell might be constructed upon the principle of that described in the above paragraph which would be of practical and commercial value.

XXXVIII. Notes on the Seat of the Electromotive Forces in a Voltaic Cell. By J. Hopkinson, M.A., D.Sc., F.R.S.*

7 HE following is an expansion of some short remarks I 1 made when Dr. Lodge's paper was read at the Society of Telegraph Engineers.

I. The controversy between those who hold that the difference of potential between zinc and copper in contact is what is deduced by electrostatic methods, and those, who hold that it is measured by the Peltier effect, is one of the relative simplicity of certain hypotheses and definitions used to represent admitted facts.

Taking thermoelectric phenomena alone, we are not imperatively driven to the conclusion that the difference of potential between zinc and copper is the small quantity which the Peltier effect would indicate; but by assuming with Sir W. Thomson that there is an electric property which may be expressed as an electric convection of heat, or that electricity has specific heat, we may make the potential difference as great as we please without contradiction of any dynamical principle or known physical fact. Let us start with the physical facts, and introduce hypothesis as it is wanted.

* Communicated by the Author. 